\title{
Receptor-Type Tyrosine-Protein Phosphatase C
}

National Cancer Institute

\section{Source}

National Cancer Institute. Receptor-Type Tyrosine-Protein Phosphatase C. NCI

Thesaurus. Code C17282.

Receptor-type tyrosine-protein phosphatase C (1304 aa, 147 kDa) is encoded by the human PTPRC gene. This protein plays a role in protein dephosphorylation. 